удк 351

E. В. Колосов,

слухач магістратури кафедри управління

охороною здоров' я та публічного адміністрування,

Національний університет охорони здоров' я України імені П. А. Шупика

ORCID ID: 0000-0001-7069-2274

C. П. Кошова,

к. держ. упр., дочент кафедри управління охороною здоров' я та публічного адміністрування,

Начіональний університет охорони здоров' я Украӥни імені П. А. Шупика

ORCID ID: 0000-0002-7637-4311

DOI: $10.32702 / 2306-6814.2021 .16 .104$

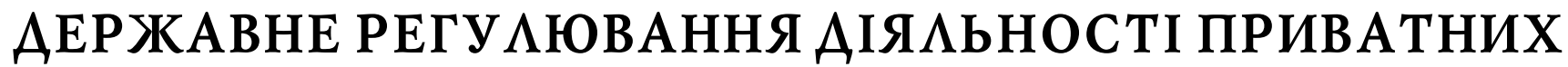 ЗАК АААІВ ОХОРОНИ ЗАОРОВ'Я
}

\author{
E. Kolosov, \\ Master's student of the Department of Healthcare Management and Public Administration, \\ Shupyk National Healthcare University of Ukraine, Kyiv, Ukraine \\ S. Koshova, \\ $\mathrm{PhD}$ in Public Administration, Associate Professor of the Department of Healthcare Management \\ and Public Administration Shupyk National Healthcare University of Ukraine, Kyiv, Ukraine
}

\section{STATE REGULATION OF PRIVATE HEALTHCARE ACTIVITIES}

Устатті досліджується державне регулювання діяльності приватних закладів охорони здоров'я у сучасній системі охорони здоров'я України. Досліджено механізм державного регулювання діяльності приватних закладів охорони здоров'я в Україні. Розглянуто інструменти державного регулювання діяльності приватних закладів охорони здоров 'я у процесі реформування системи охорони здоров'я України та її подальшого розвиткуз постійним підвищенням якості медичних послуг як на регіональному, так і на державному рівні. Проаналізовано поточний стан галузі приватної медицини у системі охорони здоров'я України. Продемонстровано, що ринок приватних медичних послуг в Україні розвивається за різновекторними тенденціями. Досліджено в регіональномі вимірі структуру ринку приватних медичних послуг України. Проаналізовані видаткові статті з державного бюджету на охорону здоров'я, при цьому порівнюючи державно видатки з приватними. Обгрунтовано необхідність розвитку приватного сектору охорони здоров'я України та окреслено найважливіші тенденції розвитку ринку приватної медицини з метою вироблення стратегій підвищення якості медичного обслуговування в XXI ст. Виявлено основні проблеми та стримуючі фактори розвитку ринку приватної медицини в Україні. Проаналізовано законодавство стосовно встановлення норм діяльності приватних закладів охорони здоров 'я та розглянуто обмеження та труднощі в процесі створення якісної нормативно-правової бази в сфері охорони здоров'я задля досягнення ефективного державного регулювання діяльності приватних закладів охорони здоров'я. Перспективи розвитку функціонування приватного сектору охорони здоров'я знаходиться у взаємозалежності не лише від поточних макроекономічних та соціальних параметрів, крім того, від імплементованої політики, якуздійснює держава в області введення реформування медичної галузі. Сформульовано рекомендації та заходи задля оптимізації та вдосконалення впровадження державного регулювання діяльності приватних закладів охорони здоров'я, які передбачають втілення комплексу заходів, а також імплементації відповідних нормативно-правових актів у цій галуззі. Визначено очікувані результати від реалізації державної політики стосовно діяльності приватних закладів охорони здоров'я. 
The article examines the state regulation of private health care facilities in the modern health care system of Ukraine. The mechanism of state regulation of private health care institutions in Ukraine has been studied. The tools of state regulation of private health care institutions in the process of reforming the health care system of Ukraine and its further development with the constant improvement of the quality of medical services at both the regional and state levels are considered. The current state of the private medicine industry in the health care system of Ukraine is analyzed. It is demonstrated that the market of private medical services in Ukraine is developing according to different vector trends. The structure of the market of private medical services of Ukraine is investigated in the regional dimension. Expenditures from the state budget for health care are analyzed, comparing public expenditures with private ones. The necessity of development of the private sector of health care of Ukraine is substantiated and the most important tendencies of development of the market of private medicine for the purpose of working out of strategies of increase of quality of medical care in the XXI century are outlined. The main problems and restraining factors of the private medicine market development in Ukraine are revealed. The legislation on setting the norms of private health care facilities is analyzed and the limitations and difficulties in the process of creating a quality legal framework in the field of health care to achieve effective state regulation of private health care facilities are considered. The prospects for the development of the private health sector are interdependent not only on the current macroeconomic and social parameters, but also on the implemented policy pursued by the state in the field of health care reform. Recommendations and measures have been formulated to optimize and improve the implementation of state regulation of private health care facilities, which provide for the implementation of a set of measures, as well as the implementation of relevant regulations in this area. The expected results from the implementation of the state policy regarding the activity of private health care institutions have been determined.

Ключові слоВа: приВатні заклади охорони здороВ'я, ринок приВатних медичних послуг, приВатний сектор медицини, держаВне регулюВання, держаВна політика, система охорони здоров'я.

Key words: private health care institutions, market of private medical services, private medical sector, state regulation, state policy, health care system.

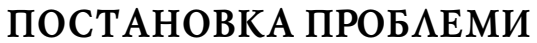

Державне регулювання діяльності приватних закладів охорони здоров'я являється системою заходів, спрямованих на підвищення адаптивності, результативності та ефективного функціонування сфери охорони здоров'я, і сконцентрована насамперед на збереження соціальної справедливості в умовах ринкових відносин, тобто гарантування та асекурація надання якісної та доступної медичної допомоги всім громадянам країни. Ринковий механізм функціонування економіки орієнтований на отримання прибутку, котрий повністю не здатен вирішувати всі соціально-економічні проблеми, в результаті чого необхідне різного ступеню державне втручання. Особливо потребує регулювання така соціально значуща сорера, як охорона здоров'я, де держава повинна контролювати, щоб економічні перетворення в цій сорері мали соціальну спрямованість.

Аналізуючи світовий досвід, який демонструє, що найбільш ефективною $є$ наступна система охорони здоров'я, в якій гармонійно та вдало здійснюють діяльність державний та приватний сектори. Оскільки поточні видатки з Державного бюджету не забезпечують належну та повноцінну діяльність державних медичних за- кладів та надання відповідної медичної допомоги, тому необхідно імплементувати загальнообов'язкове медичне страхування та переглянути значення приватного сектору медицини та надати йому більший соціальний статус і розширити можливості для фрнкціонування приватних закладів охорони здоров'я, який зменшить поточне навантаження на державну систему охорони здоров'я. Оскільки сорера охорони здоров' я повинна забезпечувати задоволення потреб громадян у якісних і доступних медичних послугах, що є вкрай важливим завданням для України, проте у зв'язку з обмеженими фрінансовими можливостями, повноцінне вирішення новітніх проблем є викликом для імплементації відповідного регулювання ринку медичних послуг, тому актуальність дослідження посилюється нагальною потребою вдосконалення законодавства стосовно державного регулювання діяльності приватних закладів охорони здоров'я України.

\section{AHA $\Lambda$ I 3 OCTAHHIX АОС $\Lambda$ IАЖЕНЬ І ПУБАІКАЦІЙ}

Тематику державного регулювання діяльності приватних закладів охорони здоров'я досліджує значна 


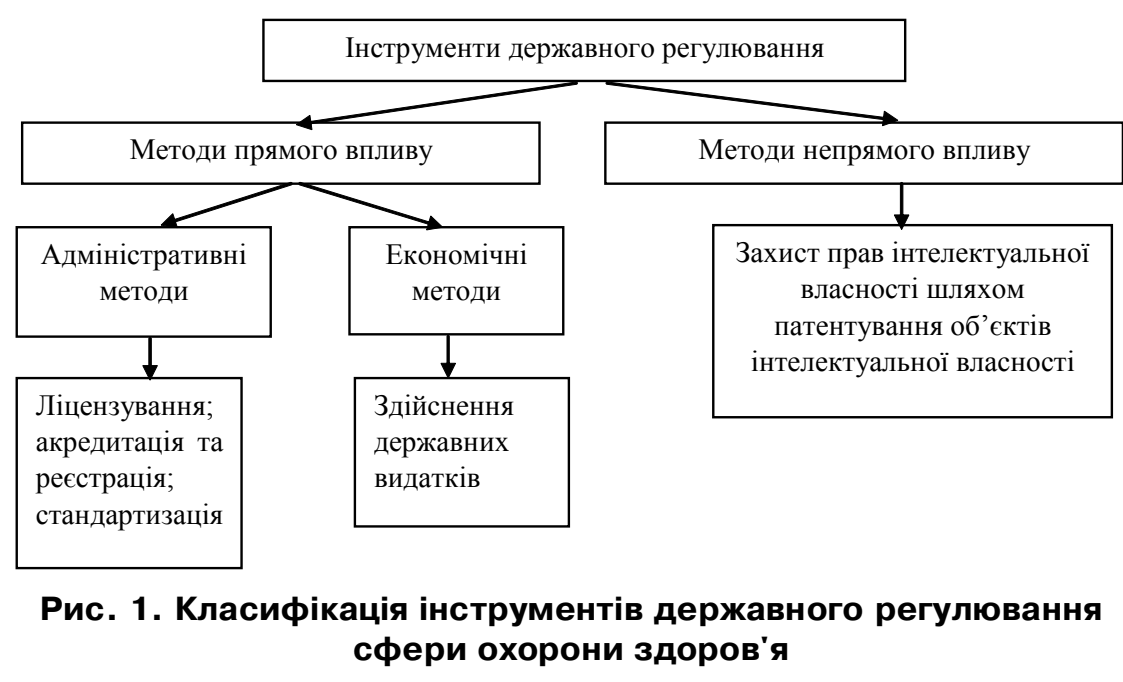

Джерело: сорормовано на основі джерела: [4, с. 172]. кількість науковців. Зокрема, наукові праці А.Д. Барзилович, В.В. Дудка, В.В. Карлаш, Г.М. Урсол, Д.М. Рябець, І.А. Голованова, І.М. Леган, І. Парубчак, Н.І. Карпишин, Н.Ю. Меловатская, О.Д. Крикун присвячені аналізу деяких аспектів застосування державного регулювання діяльності приватних закладів охорони здоров'я у рамках сучасних викликів, які вплинули на розвиток та становлення діяльності сфери охорони здоров'я. Значну роботу з аналітичної оцінки приватної медичної сфери здійснюють експерти Міністерства охорони здоров'я України. Варто відзначити, що досі залишаються невирішеними чимало питань, пов'язаних з опрацюванням та імплементацією у практичну діяльність ефективних механізмів державного регулювання діяльності приватних закладів охорони здоров'я.

\section{META I 3АВAАНHЯ CTATTI}

Метою роботи є дослідження державного регулювання діяльності приватних закладів охорони здоров'я. Для досягнення мети визначено такі завдання: в загальних рисах проаналізувати державне регулювання діяльності приватних закладів охорони здоров'я; проаналізувати сучасний стан ринку приватних медичних послуг та медичної галузі України; запропонувати превентивні заходи щодо реалізації державного регулювання діяльності приватних закладів охорони здоров'я. Під час проведення дослідження було використано загальнонаукові й спеціальні методи дослідження, зокрема аналіз і синтез, порівняння, узагальнення, системно-структурний аналіз, статистичний аналіз, графрічний та аналітичний методи.

\section{ВИК ААА ОСНОВНОГО МАТЕРІААУ АОСАIАЖЕННЯ}

Державне регулювання ринку діяльності приватних закладів охорони здоров'я $є$ складною системою, що призначене для досягнення поставлених цілей, яке має визначену структуру, сукупність правових норм, методи, засоби, інструменти державного впливу на об'єкт управління та скероване для реалізації відповідної політики у визначеній сорері суспільного розвитку, що дає можливість визначити основні напрями управлінських впливів під час проведення реформування галузі. У нових економічних умовах Україна потребує реформуван- ня державного управління діяльності приватних закладів охорони здоров'я задля ефективного інтегрування в структуру країн Європейського Союзу. Ефективність управлінської діяльності визначається рівнем раціональної організації керованої системи і процесом управління. Підвищення ефективності системи державного управління діяльності приватних закладів охорони здоров'я вимагає пошуку найкращих організаційних фоор, методів, технологій відповідно до встановлених критеріїв оцінки результатів. У якості таких можуть виступати критерії раціональної організації системи та її складових елементів, управлінської праці та самого процесу управління, рівень управлінської кваліфрікації керівних кадрів [1, с. 155].

Оскільки головною метою механізму державного управління діяльності приватних закладів охорони здоров'я являється забезпечення якості надання медичних послуг населенню та забезпечення принципів доброчесної та вільної конкуренції на ринку. Слід зазначити, що для реалізації головної мети регулювання діяльності приватних закладів охорони здоров'я держава визначає тактичні цілі, основні завдання, напрями та принципи державної регуляторної політики.

Якщо розглядати ринок медичних послуг як певну систему взаємодії соціально-політичних інститутів, то слід зазначити, що суб'єкти, які здійснюють діяльність, пов'язану з наданням медичних послуг і на яку спрямовано регуляторний вплив держави, функціонують у системі відносин інституту державної медицини, приватної підприємницької діяльності з надання медичних послуг, суспільно-громадського інституту, що уособлює населення як споживача медичних послуг, який висуває вимоги та потреби для підтримки свого здоров'я, та окремого регуляторного інституту - системи норм та правил регулювання діяльності суб'єктів ринку, функції якого нині виконують підрозділи Міністерства охорони здоров'я України, а також функціонування посередницького інституту страхової медицини. Загальна національна система охорони здоров' я $€$ також інститутом, але більш масштабним, в якому перетинаються взаємозв'язки між усіма зазначеними інститутами [2, с. 87].

Міністерство охорони здоров'я України, зокрема департаменти в його складі, що спеціалізуються на контролі якості надання медичних послуг, представлені Директоратом медичних послуг, Медичним департаментом, Управлінням ліцензування та контролю якості надання медичних послуг, Управлінням екстреної медичної допомоги та медицини катастрофр. Ці підрозділи забезпечують розроблення інструментів ефективного функціонування національної системи медичного обслуговування, програм державних замовлень, здійснюють діяльність із планування й прогнозування, стандартизації, сертифрікації з метою забезпечення роботи медичних лікарень, клінік, приватних закладів та інших установ, що надають медичне обслуговування, необхідними ресурсами та контролю процесу надання ними медичних послуг [3]. 


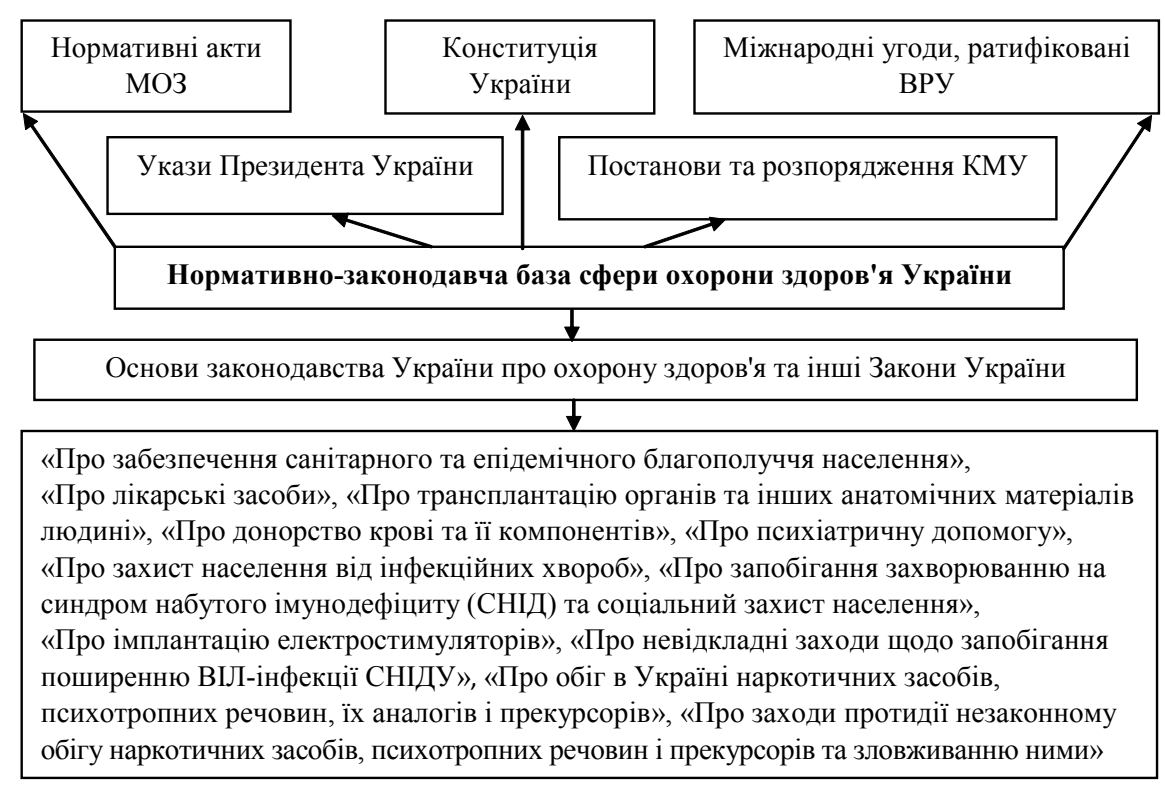

Рис. 2. Нормативно-законодавча база сфери охорони здоров'я Украйни

Джерело: сформовано на основі джерела: [16].

Головними органами, що гарантують забезпечення виконання першочергових завдань і запланованих заходів у галузі регулювання, залишаються частково підрозділи Міністерства охорони здоров'я України. Деякими регуляторними функціями опосередковано займається новостворена у 2017 р. у межах заходів із реалізації медичної рефрорми Національна служба здоров'я України, яка являється національним страховим органом, який забезпечує населення відповідним гарантованим пакетом медичних послуг в діапазоні визначеного фріскального простору [2, с. 88].

Інструментарій державного регулювання діяльності приватних закладів охорони здоров'я розглядаємо як цілісність методів та принципів, поетапністю яких $є$ взаємовигідність суб'єктів господарювання з ціллю кількісного та якісного впливу на задоволення медичних потреб суспільства та сталий розвиток діяльності на ринку медичних послуг. Використання інструментів має бути направлено на підвищення ефективності фрункціонування й конкурентоспроможності, типізованими критеріями якої має бути доступність медичної допомоги, рівень та якість медичних послуг, максимальне використання усіх ресурсів, оптимізація процесу менеджменту завдяки удосконаленню принципів, підходів та функцій управління. Класифікацію інструментів державного регулювання сфери охорони здоров' я наведено на рисунку 1.

Як видно з рисунка, класифрікація інструментів державного регулювання сорери охорони здоров'я поділяється на методи прямого та непрямого впливу. До методів прямого впливу належать адміністративні (ліцензування; акредитація та реєстрація; стандартизація) та економічні (здійснення державних видатків). Під час регулювання сорери охорони здоров'я методи непрямо-

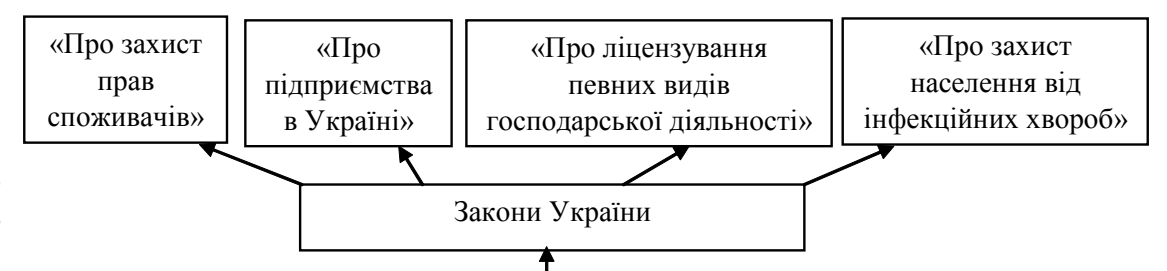

\begin{tabular}{|c|}
\hline Нормативно-законодавча база діяльності приватних закладів охорони \\
здоров’я
\end{tabular}

Рис. 3. Нормативно-законодавча база діяльності приватних закладів охорони здоров'я

Джерело: срормовано на основі джерела: [17].

\begin{tabular}{|c|}
\multicolumn{1}{c|}{ Вимоги до діяльності приватних закладів охорони здоров'я } \\
\hline $\begin{array}{l}\text { Наявність та відповідність приміщень установленим санітарним нормам і правилам, } \\
\text { які засвідчуються висновком закладу державної санітарно-епідеміологічної служби }\end{array}$ \\
$\begin{array}{l}\text { Наявність приладів, обладнання, оснащення відповідно до Табеля оснащення } \\
\text { виробами медичного призначення лікувальних та діагностичних кабінетів } \\
\text { амбулаторно-поліклінічних закладів, що затверджуються МОз України, де засоби } \\
\text { вимірювальної техніки повинні обов'язково метрологічно перевірені }\end{array}$ \\
\hline
\end{tabular}

Рис. 4. Вимоги до діяльності приватних закладів охорони здоров'я

Джерело: срормовано на основі джерела: [17]. 
Спеціальні вимоги до діяльності приватних закладів охорони здоров'я

Дотримання вимог стосовно ведення медичної звітної документації відповідно до форм державної статистичної звітності та подання звітів до територіальних органів й обласних центрів медичної статистики в установлені терміни

$\rightarrow$
$\rightarrow$ Надання першої невідкладної медичної допомоги хворим, які перебувають у критичному для життя стані, а також у разі нещасного випадку та гострих захворювань

Дотримання вимог професійної етики і деонтології, збереження лікарської таємниці, крім випадків, передбачених законодавчими актами

Дотримання вимог Порядку та умов обов'язкового страхування медичних працівників та інших осіб на випадок інфікування вірусом імунодефіциту людини

$\rightarrow$ під час виконання ними професійних обов'язків, а також на випадок настання у зв'язку з цим інвалідності або смерті від захворювань, зумовлених розвитком ВІЛінфекції

\section{Рис. 5. Спеціальні вимоги до діяльності приватних закладів охорони здоров'я}

Джерело: сформовано на основі джерела: [17].

го впливу (захист прав інтелектуальної власності шляхом патентування об'єктів інтелектуальної власності) не використовуються [4, с. 172-173].

Регулюючи ринок медичних послуг держава виконує такі дві фрункції: соціальну та економічну. Сутність першої полягає в забезпеченні справедливості та доступності для всього населення, незалежно від рівня доходів громадян та статусу, а економічна функція полягає у забезпеченні конкуренції між надавачами медичних послуг, вдосконаленні системи ліцензування та акредитації медичних установ, забезпеченні якісного рівня медичного обслуговування, використанні податкових інструментів при регулюванні підприємницької діяльності [5].

Державне регулювання сорери охорони здоров'я в Україні грунтується на такій нормативно-законодавчій базі відображеній на рис. 2.

Відповідно до спільного Наказу Держпідприємництва України та МОЗ України від 16.01.2001 р. № 38 /63, зареєстрованого в Міністерстві юстиції України 02.03.2001 р. за № 189/5380 та введеного в дію 3 13.03.2001 р. при здійсненні господарської діяльності з медичної практики, окрім вказаних вище Законів України, ліцензіат повинен дотримуватися таких вимог (див. рис. 3).

Відповідно до п. 2.1.3 спільного Наказу Держпідприємництва України та МОЗ України від 16.01.2001 p. № 38/63, господарська діяльність суб'єктів з окремих видів медичної практики здійснюється на підставі ліцензії та за наявності таких вимог (див. рис. 4).

Відповідно до п. 2.1.4 спільного Наказу Держпідприємництва України та МОЗ України від 16.01.2001 p. № 38 /63 передбачено, що приватні заклади охорони здоров'я при реалізації медичної практики не мають права видавати листка непрацездатності.

Кваліфрікаційні вимоги до приватних закладів охорони здоров'я визначені в п. 2.2.1 2.2.5 спільного Наказу Держпідприємництва України та МОЗ України від 16.01.2001 р. № 38/63. Спеціальні вимоги визначені в п. 2.3.1, до приватних закладів охорони здоров'я, які повинні дотримуватися таких вимог (див. рис. 5) [17].

Також приватний сектор охорони здоров' я робить вагомий внесок у фрінансування медичної галузі, забезпечує її необхідною кількістю медикаментів, товарів і виробів медичного призначення, щорічно розвантажуючи державний бюджет охорони здоров' я України майже на 2 млрд грн [6]. За п'ять років фрінансування за рахунок приватного сектору збільшилося на $19435 \mathrm{млн}$ грн, приватні витрати на охорону здоров'я в Україні склали понад 42,3\% від загальних видатків охорони здоров'я, у 2018 рокі поточні витрати на охорону здо-

Таблиця 1. Загальні витрати на охорону здоров'я за фінансуючими організаціями (фінансовими агентами)

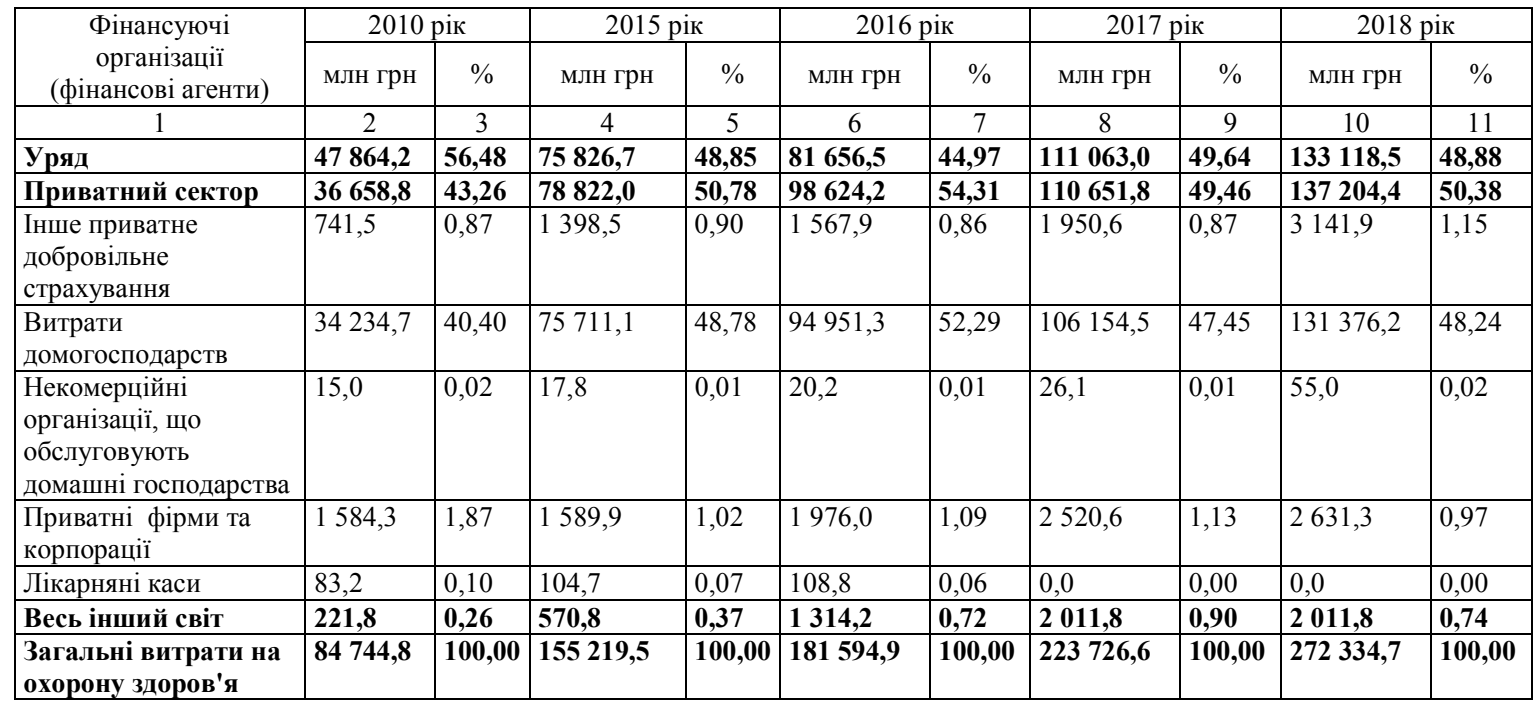

Джерело: сорормовано на основі джерела: [8]. 
Таблиця 2. Мережа приватних закладів охорони здоров'я в Україні

\begin{tabular}{|c|c|c|c|c|c|c|c|c|c|}
\hline Показники & 2010 & 2013 & 2014 & 2015 & 2016 & 2017 & 2018 & 2019 & 2020 \\
\hline $\begin{array}{l}\text { Лікарняні заклади приватної } \\
\text { власності }\end{array}$ & 92 & 97 & 81 & 84 & 90 & 104 & 131 & 147 & - \\
\hline $\begin{array}{l}\text { Заклади, які надають } \\
\text { амбулаторно-поліклінічну } \\
\text { допомогу приватної } \\
\text { власності }\end{array}$ & 1574 & 1811 & 1593 & 1701 & 1763 & 1848 & 1864 & 1972 & - \\
\hline $\begin{array}{l}\text { Заклади, які надають } \\
\text { амбулаторно-поліклінічну } \\
\text { допомогу, крім того, } \\
\text { приватні кабінети }\end{array}$ & 5510 & 5655 & 4852 & 4986 & 5046 & 5344 & 6437 & 6055 & - \\
\hline Аптеки & - & - & - & - & - & - & 20549 & 20647 & 19924 \\
\hline Загальна чисельність & 7176 & 7563 & 6526 & 6771 & 6899 & 7296 & 28981 & 28821 & 19924 \\
\hline
\end{tabular}

Джерело: ссрормовано на основі джерела: [10].

ров'я перевищили державні витрати та становили 137 млрд грн (див. табл. 1) [7].

Варто відзначити, що приватні лікувально-профрілактичні заклади знімають навантаження з державних лікарень та поліклінік. Попри значну чисельність закладів державної медицини, з кожним роком спостерігається тенденція збільшення поточної кількості пацієнтів, які хочуть обслуговуватися у приватних медичних кабінетах або приватних медичних центрах та готові оплачувати надані медичні послуги. До цієї групи належать платоспроможні клієнти, які пред'являють попит на високотехнологічне, ефективне, якісне медичне лікування та оперативність, а кількість таких пацієнтів становить понад 10\% населення України. Стосовно складової структури надаваних медичних послуг, то приватна охорона здоров'я частково доповнює державний сектор, пропонуючи інші види медичних послуг, проте вона в основному замінює його або виступає в якості альтернативи [6].

Основними конкурентними перевагами приватних медичних закладів являються: якісна діагностика та лікування у зв'язку із наявністю в кадровому штаті та поміж консультантів практично всіх необхідних лікарів, які злагоджено працюють у команді, доступність до медичних послуг, достатній час на проведення огляду, відповідальність та організоване відношення до процесу лікування пацієнта, уважний та ввічливий медичний персонал, комфортабельний та приємний інтер'єр у самому приватному медичному закладі [9, с. 23].

Процеси глобалізації соціальних та економічних відносин та становлення і розвиток науково-технічного прогресу надали можливості доступу до нових ринків лікарських препаратів для представників приватного медичного бізнесу. Завдяки інформаційним технологіям медичні працівники приватного сектору мають доступ до маркетингової, комерційної та управлінської інфрормації і можуть отримувати дані стосовно процесів організації медичного бізнесу за кордоном, дізнаватись інформацію стосовно вартості медичних послуг, про поточний рівень фрінансових доходів медичного персоналу, про управлінські заходи та навички в системі охорони здоров'я. Завдяки дослідженню поточного ефективного світового досвіду щодо функціонування медичних закладів сприяло становленню приватних медичних установ. Сьогодні в охороні здоров'я функціонує понад 28 тис. приватних медичних закладів, серед яких найбільшу чисельність становлять аптеки 71,6\% та кабінети приватних лікарів близько $21 \%$ приватного медичного сектору (див. табл. 2) [9, с. 22].

Аналізуючи ринок приватних медичних установ, то основна частка зосереджена загалом в урбанізованих районах країни [9, с. 22-23]. Домінуючу частку ринку медичних послуг станом на кінець 2018 року займає місто Київ із показником у $48,4 \%$, наступними областя-

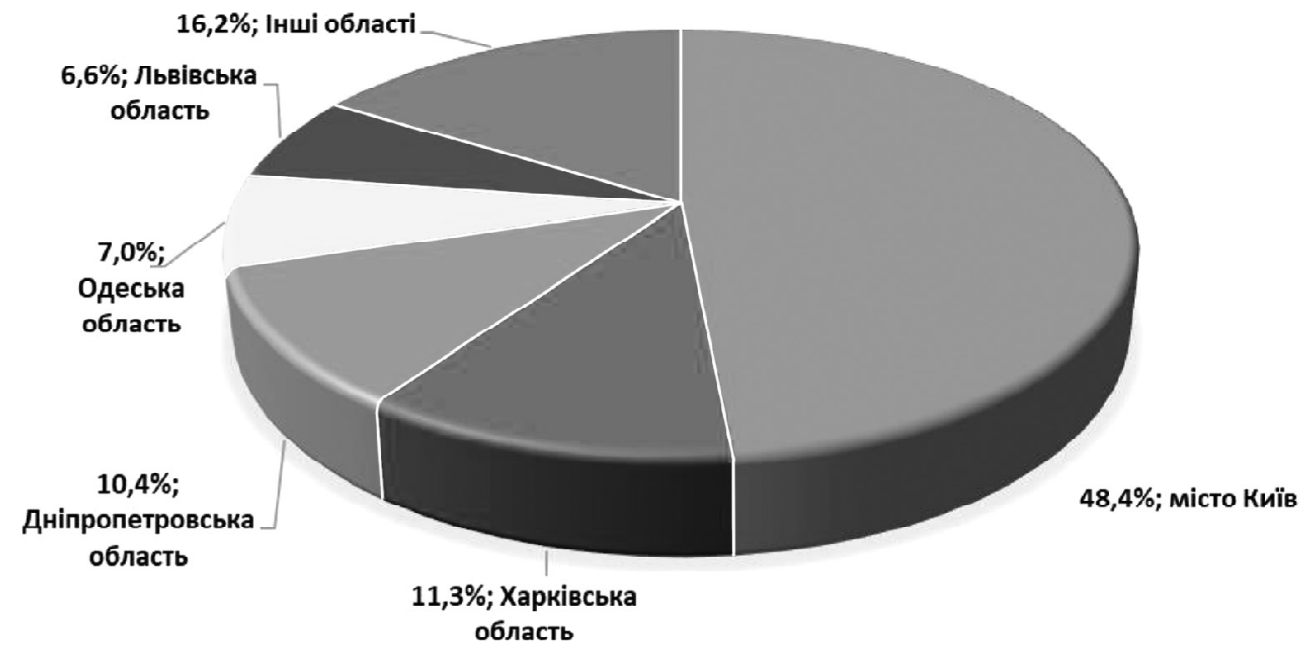

Рис. 6. Регіональна структура ринку приватних медичних послуг в Україні у 2018 році, \%

Джерело: сорормовано на основі джерела: [2]. 
ми зі значною кількістю медичних закладів $€$ Харківська $(11,3 \%)$, Дніпропетровська $(10,4 \%)$, Одеська (7\%) та Львівська (6,6\%) (див рис. 6). В основному ці приватні заклади зосереджені в обласних центрах із значною чисельністю населення, де відбувається стрімке економічне зростання, що являється вигідною умовою для розвитку та становлення приватної медицини.

Протягом тривалого періоду часу функціонування приватних медичних закладів на території країни, деякі з них займають передові позиції у цьому секторі, де статистичні показники прибутків коливаються в межах від десяти до сотні мільйонів гривень [2].

Також приватні медичні заклади повинні дотримуватися і вести відповідну конкурентну цінову політику, задля того щоб підтримувати поточні позиції своєї установи, яка б задовольняла та влаштовувала самі установи та їх постійних клієнтів. Поточна цінова політика залежить від ситуації, яка сформувалася на медичному ринку України, у зв'язку з девальвацією національної валюти, набагато важче підтримувати стабільні ціни, про що свідчать статистичні дані, що за останні декілька років поточна вартість на медичні послуги, які надають приватні медичні заклади та лабораторії зростала. У деяких приватних медичних закладах ціна змінювалась практично кожного місяця, у зв'язку та взаємозалежністю від сфрери надання послуги, обладнання, яке застосовується для проведення відповідних маніпуляцій, за рік вартість у деяких медичних приватних центрах зросла до $50 \%$ [11].

Приватний сектор медицини являється величезним резервом для надання доступних та якісних медичних послуг, проте існує ряд проблемних питань, які сповільнюють темпи розвитку приватного сектору сорери охорони здоров'я, до яких відносяться: недосконалість законодавчої та нормативно-правової бази у сфері охорони здоров'я, диспропорційні умови конкуренції приватних медичних установ із державними та відомчими лікувально-профрілактичними закладами у зв'язку з різноманітними умови доступу до матеріальних та адміністративних ресурсів; висока вартість медичних послуг у приватних медичних закладах; досить непрозорий ринок медичних послуг через цілком повну відсутність статистичних даних в області приватної охорони здоров'я; недостатня чисельність орендованих приміщень для відкриття приватних медичних установ та кваліфрікованого медичного персоналу, а також проблеми у неготовності сприйняті новітніх технологій медичними працівниками [12].

Перспективи розвитку функціонування приватного сектору охорони здоров' я знаходиться у взаємозалежності не лише від поточних макроекономічних та соціальних параметрів, крім того, від імплементованої політики, яку здійснює держава в області введення рефрормування медичної галузі. Україна солідаризується із процесом становлення приватного сектору в медичній сорері: щорічно МОЗ України надає орієнтовно 2000 ліцензій на проведення господарської діяльності в медичній практиці фрізичним особам-підприємцям та юридичним особам.

Оскільки найголовнішим являється один із законопроєктів з питань запровадження загальнообов'язкового державного соціального медичного страхування, котрий внесений на розгляд до парламенту України, та демонструє можливість участі в системі страхування медичних установ недержавної форми власності. Загалом уряд країни здійснює незначну кількість відповідних кроків задля розвитку державно-приватного партнерства у сфері охорони здоров'я, з метою створення системи впровадження результатів науково-технічної діяльності в практику охорони здоров'я. Головною причиною цього процесу являється неготовність держави до такого виду співробітництва, недосконалість поточної системи управління та адміністрування розвитком державно-приватного партнерства, відсутність сталого розмежування відповідних повноважень посеред органами державної влади, неналежне їх кадрове забезпечення, відсутність ефективного механізму надання державної підтримки у сорері державно-приватного підприємництва [13, с. 178-180].

Першочерговим напрямом удосконалення державного регулювання діяльності приватних закладів охорони здоров'я $є$ включення до Указів Президента України, Постанов уряду України, Законів України, які стосуються реформи охорони здоров'я, декларування повної рівноправності приватної і державної медицини в усіх сфрерах діяльності. На законодавчому рівні мають бути чітко прописані обмеження для суб'єктів приватної медичної діяльності з надання медичних послуг та медичної допомоги певного виду, оскільки імплементація такого обмеження $є$ не тільки цілком обгрунтованим, ай необхідним заходом.

Оскільки стосовно діяльності приватних медичних установ відсутні спеціальні законодавчі заборони і обмеження на здійснення ними окремих видів діяльності, вказує на те, що в Україні створені рівні можливості для функціонування медичних установ різних форм власності. Це у свою чергу свідчить про недосконалість і прорахунок у правовому регулюванні ринку приватної медицини. 3 огляду на це обов'язковим $€$ створення на законодавчому рівні такого ставлення до приватної медицини, за якого вона сприймалася б не як звичайний різновид підприємницької діяльності, а як необхідна і невід'ємна частина системи охорони здоров'я, що виконує важливу соціальну функцію, яка сприятиме введенню приватної медицини в жорсткі правові межі.

Тому необхідно обмежити діяльність приватних медичних закладів за допомогою прямого перерахування у законодавчих документах з охорони здоров'я видів медичної допомоги та медичних послуг, надання яких $є$ забороненим для суб'єктів приватної медичної діяльності, включивши до переліку цих послуг лікування небезпечних захворювань й вчинення медичних маніпуляцій, які потребують особливого державного контролю, а також створення на всіх рівнях державних органів управління охороною здоров'я підрозділів з розвитку ринку приватної медицини [14].

Наступним важливим напрямом удосконалення державного регулювання ринку приватної медицини являється цивільно-правове. Пріоритет повинен віддаватися диспозитивним правовим нормам, зокрема тим, які діють лише у випадках, не врегульованих цивільно-правовими договорами. Нині цивільне законодавство тяжіє до встановлення імперативних норм, що регулюють діяльність охорони здоров'я, договір же встановлює 
лише ті особливості надання медичних послуг, які не врегульовані законодавством України, включаючи накази відповідних відомств. Розвиток громадянського законодавства в даній сфері має здійснюватися випереджальними темпами, з урахуванням досвіду розвинених країн світу.

Одним із найважливіших питань, яке сьогодні потребує державного регулювання, $\epsilon$ норми податкового кодексу, які різними способами створюють певні перепони, наприклад, будь-яке підприємство чи бізнес в Україні не може прямо сплатити кошти медичному закладу за послуги, які отримують його співробітники. Іншим питанням $є$ податок на додану вартість, адже сьогодні норма Податкового кодексу України має суперечливі значення щодо податку на додану вартість із приводу медичної послуги. Наприклад, податок на додану вартість має бути нарахований на такий вид медичної допомоги, як профрілактичний огляд, що суперечить проорілактичному напряму медицини взагалі [15].

Отже, задля ефективного розвитку та становлення приватного сектору у сорері охорони здоров'я України передусім необхідно сорормувати відповідну нормативно-правову базу, яка регламентуватиме та визначатиме поточну діяльність приватних медичних закладів.

\section{ВИСНОВКИ 3 ПРОВЕАЕНОГО АОС АІАЖЕННЯ}

3 огляду на зазначене та з урахуванням ступеня розвитку ринку приватних медичних послуг, рівня надання медичних послуг, політичної й економічної ситуацій в Україні, а також економіко-соціального становища населення, удосконалення діяльності приватних закладів охорони здоров'я має здійснюватися шляхом поступової реалізації передбачених заходів на базі наявної інфрраструктури ринку надання медичних послуг. Забезпечення населення країни якісною медичною допомогою залежить від вирішення таких економічних завдань, як вдосконалення системи надання платних медичних послуг, підготовка кадрів, впровадження нових технологій у сорері охорони здоров'я. Рішення цих завдань можливо тільки у разі створення досконалого державного механізму, що дозволятиме об'єктивно аналізувати та оцінювати потреби у фрінансових ресурсах, планувати та оптимізувати потоки їх формування та використання. Отже, перед державним регулюванням діяльності приватних закладів охорони здоров'я стоять два основні завдання: забезпечення ефективності та якості у надані медичних послуг.

Станом на сьогодні в Україні сорормовані сприятливі умови для розвитку приватного сектора у сфері охорони здоров'я, проте необхідно сформувати справедливий ринок конкуренції між приватними медичними закладами. На ринку приватного сектору налічується близько 30 тис. приватних медичних закладів, які постійно намагаються укріпитися в нових сучасних умовах на ринку медичних послуг України. Процес становлення та розвитку приватного сектору, очевидно, може стати важливим фактором підвищення ефективності діяльності всієї системи охорони здоров'я й розширення доступу до якісної медичної допомоги населенню. Тому екстраординарного значення набуває імплементація активної державної політики, зосередженої на фрормування умов для ефрективного функціонування приватних медичних установ.

Основними перспективами подальших досліджень взаємопов' язані з становленням приватної медицини як сектору, який полегшить поточне навантаження державної медицини та сприятиме ефективному функціонуванню медичної галузі. Тому необхідною є розробка дієвої державної системи сприяння розвитку ринку приватної медицини як соціально значущого сектору економіки країни.

\section{Література:}

1. Парубчак І. Основні аспекти взаємодії органів державної влади та молодіжних і громадських організацій у реформуванні системи охорони здоров'я України. Публічне управління: теорія та практика: збірник наукових праць Асоціації докторів наук з державного управління. Харків: Видавництво "ДокНаукДержУпр", 2012. № 2 (10). С. 154-159.

2. Барзилович А.Д. Механізми державного регулювання надання медичних послуг в Україні. Публічне управління та митне адміністрування. Серія: Державне управління. 2020. № 1 (24). С. 86-90.

3. Міністерство охорони здоров'я України. МОЗ України: Що було, є і буде: офріц. сайт. URL: https:// moz.gov.ua/uploads/2/13773-transition_book_healthcare.pdf (дата звернення 22.03.2021).

4. Рябець Д.М. Державне регулювання сфери охорони здоров'я: принципи, механізм та інструменти. Економічні горизонти. 2018. № 4 (7). C. 164-174. DOI: 10.31499/2616-5236.4(7).2018.212757 (дата звернення 22.03.2021).

5. Карпишин Н.І. Медичне страхування у контексті модернізації фрінансового забезпечення охорони здоров'я в Україні. Формування ринкових відносин в Україні. 2013. № 11. С. 156-162.

6. Дудка В.В. Переваги приватної медицини та вигоди держави у підтримці розвитку приватного сектора системи охорони здоров'я (до проблеми державного регулювання здоровоохоронної сорери). Електронне наукове фахове видання "Державне управління: удосконалення та розвиток". 2012. № 1. URL: http://nbuv.gov.ua/UJRN/Duur_2012_1_4 (дата звернення 22.03.2021).

7. Національна стратегія побудови нової системи охорони здоров'я в Україні на період 2015-2025 рр., м. Київ, листопад 2014 р. URL: http://healthsag.org.ua/ wp-content/uploads/2014/11 (дата звернення 22.03.2021).

8. Оріційний веб-сайт Центру медичної статистики MO3 України. URL: http://medstat.gov.ua/ukr / MMXIX.html (дата звернення 22.03.2021).

9. Голованова І.А. Значення приватної медицини в системі охорони здоров'я України. Економіка і право охорони здоров'я. 2016. № 1. С. 22-25. URL: http:// nbuv.gov.ua/UJRN/eprozd_2016_1_6 (дата звернення 22.03.2021).

10. Центр медичної статистики МОЗУкраїни. Медичні кадри та мережа закладів охорони здоров'я системи МОЗ 
України за 2018-2019 роки. URL: http://medstat.gov.ua/ukr/MMXIX.html (дата звернення 22.03.2021).

11. Медексперт. URL: https://medexpert.ua (дата звернення 22.03.2021).

12. Меловатская Н.Ю. Статистический анализ и прогнозирование развития рынка платных медицинских услуг: автореф. дис. на получение науч. степени канд. эконом. наук: спец. 08.00.12 "Бухгалтерский учет, статистика". Москва, 2011.20 с.

13. Урсол Г.М. Приватний сектор системи охорони здоров'я - активний резерв підвищення доступності та якості надання медичної допомоги: досвід Кіровоградської області. Буковинський медичний вісник. 2014. Т. 18, № 4 (72). С. 177-181.

14. Леган І.М., Крикун О.Д. Напрями вдосконалення державного регулювання ринку приватної медицини. Вчені записки Таврійського національного університету імені В.І. Вернадського. Серія: Державне управління. 2020. Т. 31 (70), № 3. С. 123-127.

15. Карлаш В.В. Державне регулювання реформуванням системи охорони здоров'я України. Інвестиції: практика та досвід. 2019. № 15. С. 121-124.

16. Поживілова О.В. Функціонування приватних закладів у сорері охорони здоров'я. URL: http://www.dridu.dp.ua/zbirnik/2011-01(5)/11povsoz.pdf (дата звернення 22.03.2021).

17. Про затвердження Ліцензійних умов провадження господарської діяльності з переробки донорської крові та її компонентів, виготовлення з них препаратів, господарської діяльності з медичної практики та проведення дезінфекційних, дезінсекційних, дератизаційних робіт (крім робіт на об'єктах ветеринарного контролю): Наказ Державного комітету України з питань регуляторної політики та підприємництва від 16.01.2001 р. № $38 / 63$. Відомості Верховної Ради України. URL: https://zakon.rada.gov.ua/laws/show / z018801\#Теxt (дата звернення 22.03.2021).

\section{References:}

1. Parubchak, I. (2012), "The main aspects of interaction between public authorities and youth and public organizations in reforming the health care system of Ukraine", Publichne upravlinnia: teoriia ta praktyka: zbirnyk naukovykh prats Asotsiatsii doktoriv nauk z derzhavnoho upravlinnia, vol. 2 (10), pp. 154-159.

2. Barzylovych, A.D. (2020), "Mechanisms of state regulation of medical services in Ukraine", Publichne upravlinnia ta mytne administruvannia. Seriia: Derzhavne upravlinnia, vol. 1 (24), pp. 86-90.

3. The official site site of the Ministry of Health of Ukraine (2019), "Ministry of Health of Ukraine: What was, is and will be", available at: https://moz.gov.ua/ uploads/2/13773-transition_book_healthcare.pdf (Accessed 22 March 2021).

4. Ryabets, D.M. (2018), "State regulation of health care: principles, mechanism and tools", Ekonomichni horyzonty, [Online], vol. 4 (7), pp. 164-174. DOI: $10.31499 / 2616-5236.4(7) .2018 .212757$.

5. Karpyshyn, N.I. (2013), "Health insurance in the context of modernization of financial security in Ukraine", Formuvannia rynkovykh vidnosyn v Ukraini, vol. 11 , pp. $156-162$.
6. Dudka, V.V. (2012), "Advantages of private medicine and the benefits of the state in supporting the development of the private sector of the health care system (to the problem of state regulation of health care)", Elektronne naukove fakhove vydannia "Derzhavne upravlinnia: udoskonalennia ta rozvytok", [Online], vol. 1, available at: http://nbuv.gov.ua/UJRN/Duur_2012_1_4 (Accessed 22 March 2021).

7. The Ministry of Health of Ukraine (2014), "National Strategy for Building a New Health Care System in Ukraine for the Period 2015-2025", available at: http://healthsag.org.ua/wp-content/uploads/2014/11 (Accessed 22 March 2021).

8. Official website of the Center for Medical Statistics of the Ministry of Health of Ukraine (2020), available at: http://medstat.gov.ua/ukr/MMXIX.html (Accessed 22 March 2021).

9. Holovanova, I.A. (2016), "The importance of private medicine in the health care system of Ukraine", Ekonomika i pravo okhorony zdorovia, [Online], vol. 1, pp. 22-25, available at: http://nbuv.gov.ua/UJRN/eprozd_2016_1_6 (Accessed 22 March 2021).

10. Center for Medical Statistics of the Ministry of Health of Ukraine (2019), "Medical staff and the network of health care facilities of the Ministry of Health of Ukraine for 2018-2019", available at: http://medstat.gov.ua/ ukr /MMXIX.html (Accessed 22 March 2021).

11. The official website of Medexpert (2020), "Medical institution", available at: https://medexpert.ua (Accessed 22 March 2021).

12. Melovatskaya, N.Yu. (2011), "Statistical analysis and forecasting of the development of the market of paid medical services", Abstract of Ph.D. dissertation, Accounting, statistics, Moscow, Russian Federation.

13. Ursol, G.M. (2014), "Private sector of the health care system - an active reserve to improve the availability and quality of medical care: the experience of Kirovograd region", Bukovynskyi medychnyi visnyk, vol. 18, no. 4 (72), pp. $177-181$.

14. Legan, I.M., Screamer, O.D. (2020), "Directions for improving state regulation of the private medicine market", Vcheni zapysky Tavriiskoho natsionalnoho universytetu imeni V.I. Vernadskoho. Seriia: Derzhavne upravlinnia, vol. 31 (70), no. 3, pp. 123-127.

15. Karlash, V.V. (2019), "State regulation by reforming the health care system of Ukraine", Investytsii: praktyka ta dosvid, vol. 15, 121-124.

16. Pozhyvilova, O.V. (2011), "Functioning of private healthcare institutions", available at: http://www.dridu.dp.ua/zbirnik/2011-01(5)/11povsoz.pdf (Accessed 22 March 2021).

17. State Committee of Ukraine on Regulatory Policy and Entrepreneurship (2001), Order "On approval of Licensing conditions for economic activity on processing of donor blood and its components, production of drugs from them, economic activity on medical practice and carrying out disinfection, disinsection, deratization works (except for works on objects of veterinary control)", available at: https:// zakon.rada.gov.ua/laws/show/z0188-01\#Text (Accessed 22 March 2021).

Стаття надійшла до редакиї 20.07.2021 p. 